American Journal of Agricultural and Biological Sciences 6 (4): 480-485, 2011

ISSN 1557-4989

(C) 2011 Science Publications

\title{
Enzymatic Bioconversion of Agave Leaves FiberHydrolysis Using Plackett-Burman Design
}

\author{
${ }^{1}$ Miguel A. Medina-Morales, ${ }^{1}$ J.C. Contreras-Esquivel, \\ ${ }^{2}$ H. De la Garza-Toledo, ${ }^{1}$ R. Rodriguez and ${ }^{1}$ Cristobal N. Aguilar \\ ${ }^{1}$ Department of Food Science and Technology, School of Chemistry, \\ Universidad Autonoma de Coahuila 25280, Saltillo, Coahuila, Mexico, \\ ${ }^{2}$ Department of Basic Sciences, Engineering Division, \\ Universidad Autonoma Agrara “Antonio Narro", 25350, \\ Buenavista, Saltillo, Coahuila, México
}

\begin{abstract}
Problem statement: Biofuels production is becoming a key factor to help decrease pollution levels and the dependency of fossil fuels. Cellulose from lignocellulosic biomass is being used as a source of raw material for biofuels production, specifically bioethanol, so many ways to use it for this purpose are being developed. Approach: Cellulose content and enzymatic depolymerization of cellulose was evaluated in this contribution. Results: Cellulose content was of $67 \%$ on fibers, which places this material as a potential raw material for bioethanol production $42 \%$ of the cellulose content of the Agave leaves fibers was released as glucose due to enzymatic degradation. Seeing the behavior of the enzymatic hydrolysis at $96 \mathrm{~h}$ a mathematical model was applied which gave a time for enzymatic hydrolysis which must result in the maximum of glucose liberated under the conditions used for the process. Conclusion: Using Agave Atrovirens at $44 \mathrm{~h}$ of enzymatic hydrolysis will provide the highest yield of glucose which can be used for other processes such as ethanolic fermentation.
\end{abstract}

Key words: Plackett-Burman Design (PBD), Enzymatic hydrolysis, cellulose degradation, Lignocellulosic residues, leaf cellulose fibers, fossil fuels, enzymatic means, cellulose depolymeryzation, cristallinity regions

\section{INTRODUCTION}

Lignocellulosic residues are becoming a potential resource of raw material for study, chemical, pharmaceutical, biomaterials (Ruiz et al., 2011, Clarence et al., 2010). Biofuels production, particularly ethanol for combustion engines (Moukamnerd et al., 2010, Zhang et al, 2010). The production of alcoholic beverages such as mezcal, are obtained through the fermentation of Agave syrup, such as Agave Salmiana or Agave Atrovirens, among others. The mezcal production process generates a residual material which are leaves or pencas. The latter material is rich in lignocellulosic fibers with industrial potential (De Leon-Rodríguez et al., 2008; Yoswathana et al., 2010). For better processing of lignocellulosic biomass, pretreatments are needed for the improval of cellulose depolymeryzation. These procedures are essential for cellulose degradation (Gupta et al., 2011). The saccharification of cellulose is an interesting procedure for the use of residual biomass being agroindustrial wastes (Martins et al., 2008, Zhang et al., 2010). The enzymatic hydrolysis or saccharification is mainly limited by several factors including cristallinity of cellulose, degree of polymerization, moisture content, available surface area, among others (Li et al., 2010). The agents responsible for cellulose degradation are cellulases. Three group of enzymes such as endoglucanase, exo-glucanase and $\beta$-glucosidase are involved in cellulose-to-glucose process with synergistically action among them (Yah et al., 2010). Endo-glucanase attacks low cristallinity regions on cellulose fiber and creates free chain-ends. Exoglucanase degrades the molecule further by removing cellobiose units from the free chain-ends which is then cleaved to glucose by the action of $\beta$-glucosidase (Talebnia et al., 2010). In this regard, the enzymatic process could be statistically analized to identify factors

Corresponding Author: C.N. Aguilar, Department of Food Science and Technology, School of Chemistry, Universidad Autónoma de Coahuila 25280, Saltillo, Coahuila, Mexico 
crucial for the improvement of cellulose degradation. The addition of experimental designs such as PlackettBurman Design (PBD) (Plackett and Burman, 1946, Fang et al., 2010) has the advantage of minimize experiments of great number of experimental units to and adjusted number of them and allows the identification of the most significant factors which have a given effect on a process. It can screen $n$ factors in $n+1$ experimental runs. The design is orthogonal in nature, the effects are independent and the interactions among factors are negligible (Yingling et al., 2011). This study evaluates the effect of the factors involved in the enzymatic saccharification of Agave leaf cellulose fibers.

\section{MATERIALS AND METHODS}

Plant material and characterization and pretreatment: Agave leaves (A. Salmiana and $A$. Atrovirens) were obtained from the vicinity of the city of Saltillo Coahuila (Fig. 1 and 2 respectively). The pencas were peeled off to leave only the fibers and then dehydrated at $70^{\circ} \mathrm{C}$ for two days so minor particle size material could be easily obtained; the dehydrated material was milled to obtain a fine powder and fibers from the pencas. Concerning characterization, the procedure cellulose content were determined by a gravimetric technique by the acid and neutral detergent fiber method (Van Soest et al., 1991), previously treated the material with $\mathrm{NaOH}$. For the pretreatment, $1 \mathrm{~g}$ of Agave fibers were submerged in $20 \mathrm{~mL}$ of distilled water and subsequent thermal activity was added in an autoclave at $121^{\circ} \mathrm{C}$ for 15,30 and $45 \mathrm{~min}$. After the process, the material was filtered and washed with tap water. The material was dehydrated for posterior hydrolysis assays.

Experimental design on enzymatic hydrolysis: Plackett-Burman Design (PBD) has the advantage of minimize experiments of great number of experimental units to and adjusted number of them and allows the identification of the most significant factors which have a given effect on a process. It can screen $\mathrm{n}$ factors in $\mathrm{n}+1$ experimental runs. The design is orthogonal in nature, the effects are independent and the interactions among factors are negligible (Yingling et al., 2011). In this experimental stage, seven variables (Table 1) were evaluated including temperature, agitation, $\mathrm{pH}$, enzyme loading (Commercial cellulase obtained from Prozyn, Brazil).
Table 1: Levels managed for the variables and the tendencies obtained by the PBD analysis

\begin{tabular}{|c|c|c|c|c|}
\hline Variables & $\begin{array}{l}\text { Low } \\
\text { level (-1) }\end{array}$ & $\begin{array}{l}\text { High level } \\
(+1)\end{array}$ & $\begin{array}{l}\text { Standard } \\
\text { effects }\end{array}$ & $\begin{array}{l}\text { Contribution } \\
(\%)\end{array}$ \\
\hline Temperature $\left({ }^{\circ} \mathrm{C}\right)$ & 46.0 & 50.00 & 4.610 & 12.34 \\
\hline Agitation (rpm) & 50.0 & 150.00 & 0.389 & 1.04 \\
\hline $\mathrm{pH}$ & 4.6 & 5.00 & -5.380 & 14.40 \\
\hline Enzyme (U/L) & 1000.0 & 2000.00 & 11.700 & 31.31 \\
\hline $\begin{array}{l}\text { Substrate }(\mathrm{g} / 20 \\
\mathrm{mL} \text { buffer })\end{array}$ & 0.4 & 0.60 & -5.930 & 15.87 \\
\hline $\begin{array}{l}\text { Tween } 80 \% \\
\text { concentration }\end{array}$ & 0.01 & 0.03 & 0.634 & 1.70 \\
\hline Agave type & A. Atrovirens & A. Salmiana & -8.720 & 23.34 \\
\hline
\end{tabular}

Table 2: Experimental matrix for the PBD

\begin{tabular}{lcrrrrrrr}
\hline & Repl & Temp & & & & & Tween \\
Run & icate & erature & Agitation & pH & Enzyme & Substrate & $80 \%$ & Agave \\
\hline 10 & 2 & 1 & -1 & -1 & -1 & -1 & 1 & 1 \\
7 & 1 & -1 & 1 & 1 & -1 & -1 & 1 & -1 \\
9 & 2 & -1 & -1 & -1 & 1 & 1 & 1 & -1 \\
13 & 2 & -1 & -1 & 1 & 1 & -1 & -1 & 1 \\
22 & 3 & 1 & -1 & 1 & -1 & 1 & -1 & -1 \\
18 & 3 & 1 & -1 & -1 & -1 & -1 & 1 & 1 \\
11 & 2 & -1 & 1 & -1 & -1 & 1 & -1 & 1 \\
24 & 3 & 1 & 1 & 1 & 1 & 1 & 1 & 1 \\
2 & 1 & 1 & -1 & -1 & -1 & -1 & 1 & 1 \\
5 & 1 & -1 & -1 & 1 & 1 & -1 & -1 & 1 \\
21 & 3 & -1 & -1 & 1 & 1 & -1 & -1 & 1 \\
23 & 3 & -1 & 1 & 1 & -1 & -1 & 1 & -1 \\
17 & 3 & -1 & -1 & -1 & 1 & 1 & 1 & -1 \\
20 & 3 & 1 & 1 & -1 & 1 & -1 & -1 & -1 \\
16 & 2 & 1 & 1 & 1 & 1 & 1 & 1 & 1 \\
12 & 2 & 1 & 1 & -1 & 1 & -1 & -1 & -1 \\
14 & 2 & 1 & -1 & 1 & -1 & 1 & -1 & -1 \\
4 & 1 & 1 & 1 & -1 & 1 & -1 & -1 & -1 \\
3 & 1 & -1 & 1 & -1 & -1 & 1 & -1 & 1 \\
6 & 1 & 1 & -1 & 1 & -1 & 1 & -1 & -1 \\
1 & 1 & -1 & -1 & -1 & 1 & 1 & 1 & -1 \\
15 & 2 & -1 & 1 & 1 & -1 & -1 & 1 & -1 \\
8 & 1 & 1 & 1 & 1 & 1 & 1 & 1 & 1 \\
19 & 3 & -1 & 1 & -1 & -1 & 1 & -1 & 1 \\
\hline & & & & & & & &
\end{tabular}

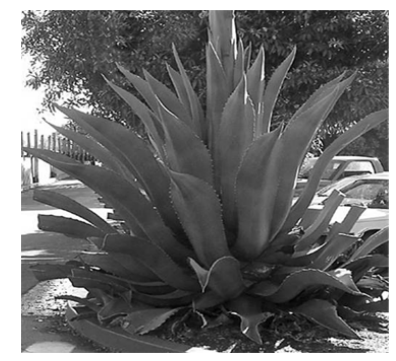

Fig. 1: Agave salmiana

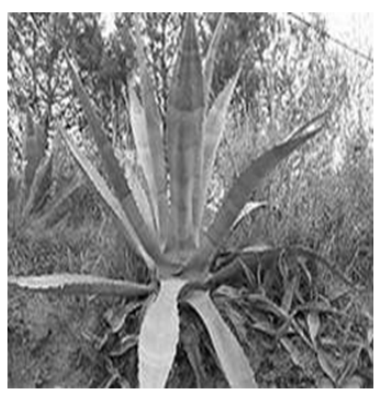

Fig. 2: Agave atrovirens 
Am. J. Agri. \& Biol. Sci., 6 (4): 480-485, 2011

This enzyme was used in the exploratory analysis substrate quantity, surfactant (Tween 80) and Agave species (A. Salmiana and A. Atrovirens). These factors were set in two levels for each one: -1 for low level and +1 for high level. The software used for generating the experimental matrix (Table 2) and for the analysis was Statistica ${ }^{\circledR}$ 7.0. All experiments were carried in triplicate. The response measured was glucose using a glucose-oxidase kit. The total time of hydrolysis was of $12 \mathrm{~h}$.

Extended time of enzymatic hydrolysis: After defining the result of the PB design and establishing which condition showed the highest yield of glucose, enzymatic hydrolysis were carried out at 48 and $96 \mathrm{~h}$. Glucose was measured by the same method described before.

Mathematical modeling of the enzymatic hydrolysis: A mathematical equation was used for the establishment of the enzymatic hydrolysis time using the following equation.

\section{RESULTS}

Plant material characterization and pretreatment: The amount of cellulose from the untreated sample of Agave pencas was ranging from $20-30 \%$ and after pretreatment both values increased to $65 \%$ approximately (Table 3). The effect that took place may have been the removal of compounds that could be interfering with cellulose detection.

PBD analysis: This analysis is used to evaluate the factors that significantly affect on a given process. In Fig. 3 the factors that had significant effect on the hydrolysis were the enzyme loading, the Agave species, substrate quantity, $\mathrm{pH}$ and temperature. Tween 80 concentration and agitation had no significant effect on the hydrolysis with 1.70 and $1.04 \%$ of contribution respectively, while the most significant variables were enzyme loading and Agave species with 31.31 and $23.34 \%$. Substrate concentration, while having a high contribution percentage, the standardized effect was 8.72. The negative effect means that if we manipulate the levels of this factor on a decreasing trend, the response (glucose liberated my enzymatic means) could be improved. On the other hand, the enzyme loading standardized effect is 11.7. This means that this factor has a positive effect. If the levels of enzyme are increased, the response can be increased as well. The effect of $\mathrm{pH}$ was also of negative standardized effect of -5.38 , so if we keep the $\mathrm{pH}$ value on relatively lower levels, the yield of liberated glucose will increase.
Table 3: Cellulose content in the Agave species evaluated with and without alkaline treatment

\begin{tabular}{|c|c|c|c|}
\hline \multirow{3}{*}{$\begin{array}{l}\text { Parameter } \\
\% \text { cellulose }\end{array}$} & \multicolumn{2}{|l|}{ No treatment } & $\mathrm{NaOH}$ \\
\hline & A. Atrovirens & A. Salmiana & A. Atrovirens A. Salmiana \\
\hline & 23.48 & 35.26 & 67.12 \\
\hline
\end{tabular}

Table 4: Conditions evaluated on the enzymatic hydrolysis

\begin{tabular}{llllllll}
\hline Run & $\begin{array}{l}\text { Temper } \\
\text { ature }\left({ }^{\circ} \mathrm{C}\right)\end{array}$ & $\begin{array}{l}\text { Agitation } \\
(\mathrm{rpm})\end{array}$ & $\begin{array}{l}\text { Enzyme } \\
\mathrm{pH}\end{array}$ & $(\mathrm{U} / \mathrm{L})$ & $\begin{array}{l}\text { Substrate } \\
(\mathrm{g})\end{array}$ & $\begin{array}{l}\text { Tween } \\
80(\%)\end{array}$ & $\begin{array}{l}\text { Type of } \\
\text { Agave }\end{array}$ \\
\hline $\mathrm{A}$ & 50 & 50 & 4.6 & 1000 & 0.4 & 0.03 & A. Salmiana \\
$\mathrm{B}$ & 46 & 150 & 5.0 & 1000 & 0.4 & 0.03 & A. Atrovirens \\
$\mathrm{C}$ & 46 & 50 & 5.0 & 2000 & 0.4 & 0.01 & A. Salmiana \\
$\mathrm{D}$ & 50 & 150 & 4.6 & 2000 & 0.4 & 0.01 & A. Atrovirens \\
$\mathrm{E}$ & 46 & 150 & 4.6 & 1000 & 0.6 & 0.01 & A. Salmiana \\
$\mathrm{F}$ & 50 & 50 & 5.0 & 1000 & 0.6 & 0.01 & A. Atrovirens \\
$\mathrm{G}$ & 50 & 150 & 5.0 & 2000 & 0.6 & 0.03 & A. Salmiana \\
$\mathrm{H}$ & 46 & 50 & 4.6 & 2000 & 0.6 & 0.03 & A. Atrovirens \\
\hline
\end{tabular}

Temperature had a positive effect with standardized effect of 4.61. In this case, if increasing temperature above the values used in this experiment, glucose liberation can improve. Substrate concentration had a $15.87 \%$ of contribution, but a negative effect with -5.93 , so decreasing the substrate levels will give a higher yield of hydrolysis. A qualitative factor was evaluated which was the type of Agave used in hydrolysis. The levels managed on this factor was at low level (-1) A. Atrovirens and at high level (+1) A. Salmiana. It was observed that the standardized affect was negative with -8.72 . This means that, if we continue using A. Atrovirens, our response will be higher. If $A$. Salmiana were to be used, response would be lower. Each one of the combination of factors and its levels, originated eight different hydrolysis conditions. The glucose obtained were quantities from 24.89$170.67 \mathrm{mg} \mathrm{glu} \mathrm{g}^{-1}$ (Fig. 4). In Table 4, the experiment coded as $\mathrm{D}$ had the highest. As explained before, $A$. Atrovirens had a positive effect on the enzymatic liberation of glucose; the highest value was obtained with this plant material.

Approximately the cellulose content on this fiber is of $67 \%$. This percentage could be considered as $670 \mathrm{mg}$ $\mathrm{glu} / \mathrm{g}$ in the form of cellulose. The D experiment had released $25.43 \%$ of the cellulose while E experiment the lowest of $3.71 \%$.

Enzymatic hydrolysis and mathematical estimation of total hydrolysis time: The experiment began with 0 glucose to ascend to the levels of a maximum of glucose liberated was of $284.53 \mathrm{mg} \mathrm{glu} \mathrm{g}^{-1}$. Extending hydrolysis time higher yields were reached. A maximum of $285 \mathrm{mg}$ glu $\mathrm{g}^{-1}$ was detected at $84 \mathrm{~h}$ of hydrolysis. 


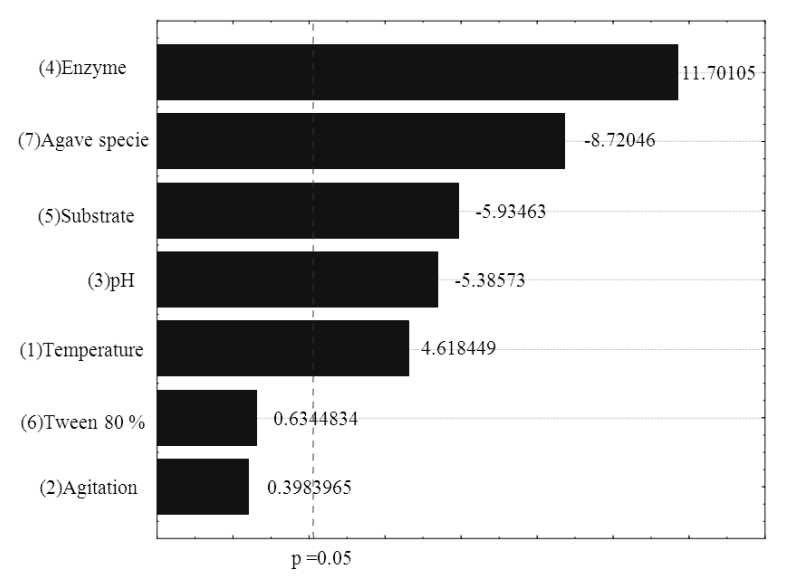

Fig. 3: Pareto chart with standardized effects of the factors evaluated on the enzymatic hydrolysis

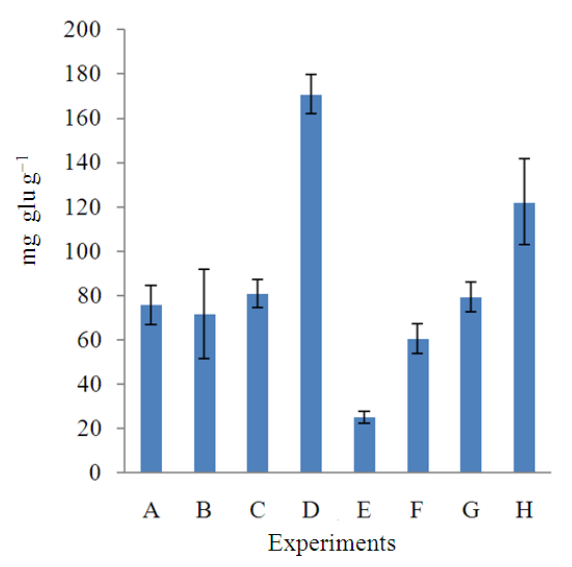

Fig. 4: Glucose yield obtained in the hydrolysis on the PBD

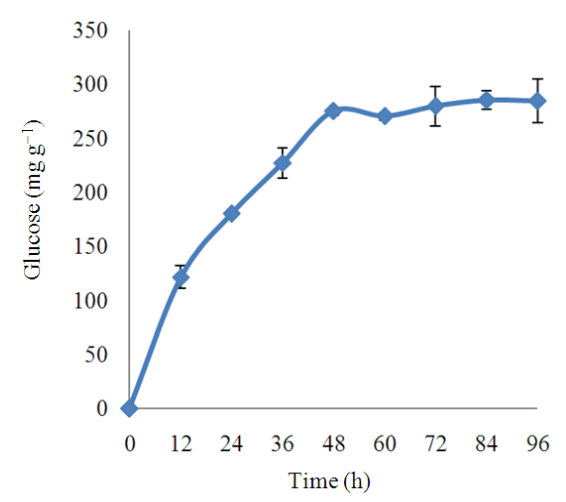

Fig. 5: Enzymatic hydrolysis of Agave atrovirens leaves fibers at $96 \mathrm{~h}$

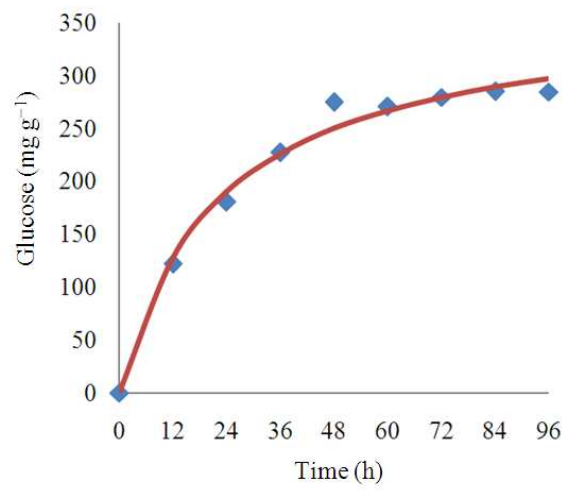

Fig. 6: Modelling of the enzymatic hydrolysis at $96 \mathrm{~h}$ for the mathematical establishment of the most adequate time of hydrolysis

In the Fig. 5 it's shown that there is no significant difference between the glucose levels of $48 \mathrm{~h}$ until $96 \mathrm{~h}$, according to the standard deviation. This behavior shows the glucose levels did not change significantly, so an equilibrium point was reached.

Having a correlation between calculated and experimental values of 0.99 , the $\mathrm{k}$ value obtained from the equation 1, was extrapolated from the $\mathrm{Y}$ axis to the $\mathrm{X}$ axis, thus giving a $44 \mathrm{~h}$ time of hydrolysis. This value of time corresponds to the maximum reached on the system at $48 \mathrm{~h}$ of hydrolysis time, so at $44 \mathrm{~h}$ is possible that is mathematically established that this time of hydrolysis is suitable for the overall process (Fig. 6). According to the mathematical model, if time is increased, a maximum of theorical glucose liberated would be of $365 \mathrm{mg} \mathrm{g}^{-1}$.

\section{DISCUSSION}

Characterization and pretreatment process: The mechanical procedures holds an important role on the process, if the particle size is reduced, this increases the available surface area for hydrolysis and also decreases the polymerization degree of the material, having and improving effect on the enzymatic hydrolysis of the lignocellulosic material (Hendriks and Zeeman, 2009). Cellulose determination showed that both Agave contain high cellulose levels of $67.12 \%$ on $A$. Atrovirens and $61.25 \%$ on A. Salmiana. On other plants, cellulose content have been reported, where stand out corn residues (40\%), coconut fiber $(43 \%)$, barley fibers (50\%), among others (Graminha et al., 2007, ). The cellulose content was modified after the alkaline treatment. In both Agave species the cellulose content was seemingly increased, from approximately $30-65 \%$. The removal of other components which may interfiere with cellulose detection promote the apparent 
increase of cellulose, such as the results showed on rice straw where the cellulose content went from approximately 40-60\% using also an alkaline treatment (Zhang and Cai, 2008; Khalil et al., 2009).

PBD analysis: The enzymatic hydrolysis can be influenced by substrate and end-product concentrations, enzyme activity and reaction conditions (Talebnia et al., 2010). This effect can be attributed to many reasons. The crystalline cellulose, which has high recalcitrance to hydrolysis, the particle size as well as the polymerization degree, affects the cellulase action on the polysaccharide. Other situation that can manifest itself on the hydrolysis is the enzymatic inhibition. Cellulases can stop their activity caused by accumulation of product, namely cellobiose. So in this case, the substrate excess that the statistical analysis is showing, can be due to insufficient cellobiohydrolase activity contained in the lignocellulolytic enzyme complex, if too much fibers are used, it is possible that cellobiose accumulates and enzymes will be inhibited. This also can be associated to the use of substrate quantity, because if adding more substrate could generate inhibition by product (Heinelman et al., 2009), so in that case the addition of $\beta$-glucosidase is proposed as an alternative to overcome that situation (Singhania et al., 2010). If the results show that the $\mathrm{pH}$ in the system must decrease in order to achieve higher glucose yields, this tendency indicates that the optimum $\mathrm{pH}$ value of this enzyme is below the used in this experiment. Temperature also indicates that increasing it will increase glucose yields, this increase needed in temperature must be relative and most of the cellulolytic complexes have their optimum temperature near $50^{\circ} \mathrm{C}$. Most cellulose enzymes show an optimum activity at temperatures and $\mathrm{pH}$ in ranges of $45-55^{\circ} \mathrm{C}$ and 4-5, respectively (Galbe and Zacchi, 2002, Daoud and Alam, 2010). The aspect that covers the effect of the Agave species on the higher yields that can potentially be obtained, rely on the usage of Agave. Atrovirens, as the statistical analysis has shown rather using Agave salmiana. Also A. Atrovirens has a higher cellulose content then A. Salmiana.

Enzymatic hydrolysis and mathematical estimation of total hydrolysis time: Using the conditions that yielded higher glucose liberation and extending time of hydrolysis, it was observed that time was a crucial aspect comparing the $12 \mathrm{~h}$ hydrolysis and 48 and 96 h. The amount of glucose is among other author report for ethanol production on different plant materials such as $P$. falcataria with $38 \%$ of cellulose hydrolysis in the form of glucose (Kaida et al., 2009) Olive tree biomass with $36 \%$ (Cara et al., 2008) and Saha and Cota (2008) with $32 \%$ to name a few; these study obtained yields lower to the $42 \%$ in this study.
Other plant materials which yielded higher cellulose hydrolysis were barley residues with $83 \%$ (Kim et al., 2008), Corn stover with $80 \%$ (Fang et al., 2010) and switchgrass with 58\% ( $\mathrm{Hu}$ and Wen, 2008), also to name a few. As it is visible in the Fig. 4, the line shows a point of apparent saturation, this kind of behavior can be adapted to mathematical models such as Monod and Michaelis-Menten equations. There is more glucose available in form of cellulose, but the conditions managed and according to the PBD analysis, the factor levels must be rearranged to increase said theorical yield, so this behavior could be modified if the conditions are further manipulated.

\section{CONCLUSION}

The PBD showed that the factors that significantly affect the hydrolysis of the fibers, the adjustment of the levels could make progress in an increase in the depolymerization of the cellulose present. Agave leaf cellulose fibers can represent a very important source of raw material for various industrial purposes, most prominently biofuels production in the form of bioethanol.

\section{ACKNOWLEDGEMENT}

We would like to thank the Mexican Council of Science and Technology (CONACyT) for the financial support during the experimental development of this study.

\section{REFERENCES}

Cara, C., E. Ruiz, J. M.Oliva, F. Sáez, E. Castro, 2008. Conversion of olive tree biomass into fermentable sugars by dilute acid pretreatment and enzymatic saccharification. Bioresource Technol., 99: 18691876. DOI: 10.1016/j.biortech.2007.03.037

Daoud, J. and M. Alam, 2010. Statistical optimization of fermentation conditions for cellulase from oil palm biomass as substrate by solid state bioconversion. Am. J. Environ. Sci., 6: 66-70. DOI: 10.3844/ajessp.2010.66.70

De Leon-Rodríguez, A., P. Escalante-Minakata, A.P. Barba and H.P. Blaschek, 2008. Optimization of fermentation conditions for the production of the mezcal from Agave Salmiana using response surface methodology. Chem. Eng. Process., 47: 7682. DOI: $10.1016 /$ j.cep.2007.08.010

Fang, H., C. Zhao and X.Y. Song, 2010. Optimization of enzymatic hydrolysis of steam-exploded corn stover by two approaches: Response surface methodology or using cellulase from mixed cultures of Trichoderma reesei RUT-C30 and Aspergillus niger NL02. Bioresource Technol., 101: 4111-4119. DOI: 10.1016/j.biortech.2010.01.078 
Galbe, M. and G. Zacchi, 2002. A review of the production of ethanol from softwood. Applied Microbio. Biotechnol., 59: 618-628. DOI: 10.1007/s00253-002-1058-9

Gupta, R., Y.P. Khasa and R.C. Kuhad, 2011. Evaluation of enzymatic saccharification of cellulosic materials. Carbohydrate polymers. 84: 1103-1109. DOI: 10.1016/j.carbpol.2010.12.074

Heinelman, P., C.D. Snow, I. Wu, C. Nguyen and A. Villalobos et al., 2009. A family of thermostable fungal cellulases created by structure-guided recombination. PNAS 2009. 106: 5451-5452. DOI: 10.1073/pnas.0901417106

Hendriks, A.T.W.M. and G. Zeeman, 2009. Pretreatments to enhance the digestibility of lignocellulosic biomass. Bioresource Technol., 100: 10-18. DOI: 10.1016/j.biortech.2008.05.027

$\mathrm{Hu}, \mathrm{Z}$. and Z. Wen, 2008. Enhancing enzymatic digestibility of switchgrass by microwave-assisted alkali pretreatment. Biochemical Eng. J., 38: 369378. DOI: 10.1016/j.bej.2007.08.001

Khalil, A., A. Al-Shawabkeh, A. Mazahreh, M. AlDamanhoory, J. Quasem, 2009. Utilization of soft wood wastes as a feed stock to produce fuel ethanol. Am. J. Eng. Applied Sci., 2: 451-455. DOI: 10.3844/ajeassp.2009.451.455

Kim, T.H., F. Taylor and K.B. Hicks, 2008. Bioethanol production from barley hull using SSA (soaking in aqueous ammonia) pretreatment. Bioresource Technol., 99: 5694-5702. DOI: 10.1016/j.biortech.2007.10.055

Li, C., B. Knierim, C. Manisseri, R. Arora and H. Scheller et al., 2010. Comparison of dilute acid and ionic liquid pretreatment of switchgrass: Biomass recalcitrance, delignification and enzymatic saccharification. Bioresource Technol., 101: 49004906. DOI: 10.1016/j.biortech.2009.10.066

Martins, L.F., D. Kolling, M. Camassola, A.J. PinheiroDillon and L. Pereira-Ramos, 2008. Comparison of Penicillium echinulatum and Trichoderma reesei cellulases in relation to their activity against various cellulosic substrates. Bioresource Technol., 99: 1417-1424. DOI: 10.1016/j.biortech.2007.01.060

Moukamnerd, C., M. Kino-Oka, M. Sugiyama, Y. Kaneko and C. Boonchird et al., 2010. Ethanol production from biomass by repetitive solid-state fed-batch fermentation with continuous recovery of ethanol. Applied Microbiol. Biotechnol., 88: 87-94. DOI: 10.1007/s00253-010-2716-y

Plackett, R.L., J.P. Burman, 1946. The design of optimum multifactorial experiments. Biometrika, 33: 305-325. DOI: 10.1093/biomet/33.4.305
Ruiz, H.A., D.S. Ruzene, D.P. Silva, F. Macieira and A. Vicente et al., 2011. Development and characterization of an environmentally friendly process sequence (Autohydrolysis and organosolv) for wheat straw delignification. Applied Biochem. Biotechnol., 164: 629-641. DOI: 10.1007/s12010011-9163-9

Saha, B. and M. Cotta, 2008. Lime pretreatment, enzymatic saccharification and fermentation of rice hulls to ethanol. Biomass Bioenergy, 32: 971-977. DOI: 10.1016/j.biombioe.2008.01.014

Singhania, R., R. Sukuruman, A. Patel, C. Larroche and A. Pandey, 2010. Advancement and comparative profiles in the production technologies using solidstate and submerged fermentation for microbial cellulases. Enzyme Microbial Technol., 46: 541549. DOI: 10.1016/j.enzmictec.2010.03.010

Talebnia, F., D. Karakashev and I. Angelikadi, 2010. Production of bioethanol from wheat straw: An overview on pretreatment, hydrolysis and fermentation. Bioresource Technol., 101: 47444753. DOI: 10.1016/j.biortech.2009.11.080

Van Soest, P.J., J.B. Robertson and B.A. Lewis, 1991. Methods for dietary fiber, neutral detergent fiber and nonstarch polysaccharides in relation to animal nutrition. J. Dairy Sci., 74: 3583-3597.

Yah, C.S., S.E. Iyuke, E.I. Unuabonah, O. Pillay, C. Vishanta and S.M. Tessa, 2010. Temperature optimization for bioethanol production from corn cobs using mixed yeast strains. OnLine J. Bio. Sci., 10: 103-108. DOI: 10.3844/ojbsci.2010.103.108

Yingling, B., Y. Zongcheng and W. Homglin, 2011. Optimization of bioethanol production during simultaneous saccharification and fermentation in very high-gravity cassava mash. Antoine van Leeuwenhoek. 99: 329-339. DOI 10.1007/s10482010-9494-5

Yoswathana, N., P. Phuriphipat, P. Treyawutthiwat, N. Eshtiaghi, 2010. Bioethanol production from rice straw. Energy Res. J., 1: 26-31. DOI: 10.3844/erjsp.2010.26.31

Zhang, B. A. Shahbazi, L. Wang, O. Diallo and A. Whitmore, 2010. Alkali pretreatment and enzymatic hydrolysis of cattails from constructed wetlands. Am. J. Eng. Applied Sci., 3: 328-332. DOI: 10.3844 /ajeassp.2010.328.332

Zhang, Q. and W. Cai, 2008. Enzymatic hydrolysis of alkali-pretreated rice straw by Trichoderma reesei ZM4-F3. Biomass Bioenergy, 32: 1130-1135. DOI: 10.1016/j.biombioe.2008.02.006 